\title{
Effects of immunostimulators on growth performance and immune response in pigs weaned at 21 days of age *
}

\author{
J.D. Kim ${ }^{4}$, Y. Hyun', K.S. Sohn' ${ }^{2}$ H.J. Woo ${ }^{3}$, T.J. Kim ${ }^{3}$ and In K. Han ${ }^{4}$ \\ 'Department of Animal Science, University of Illionois Urbana 61801. USA \\ 'Agribrands Purina Korea, Inc. \\ ${ }^{3}$ College of Veterinary Medicine, Seoul National University \\ Suweon 44I-744, Korea \\ 'Department of Animal Science and Technology, \\ College of Agriculture and Life Sciences, Seoul National University
}

Suweon 441-744, Korea

(Received 7 October 1999; accepted 8 May 2000)

\section{ABSTRACT}

One hundred and fifty pigs with an average body weight of $6.6 \mathrm{~kg}$ were allotted to treatment in a completely randomized block design. The treatments included: 1. Control (basal diet), 2. P-glycan (basal diet +40 ppm peptidoglycan), 3. MOS (basal diet $+0.1 \%$ mannanoligosaccharides), 4 . MG (basal diet $+0.4 \% \beta$-glucan) and 5 . NIS (basal diet $+300 \mathrm{ppm}$ Nonspecific Immunostimulating Anionic Alkali Solution, rice bran was used as a carrier). Each treatment had 6 replicates with 5 pigs per replicate. Overall. although there were no significant differences in animal performance, pigs fed MOS showed better growth performance and feed efficiency than the other groups. Nutrients and amino acid digestibilities were improved during phase II (d 15 to 28 post-weaning) compared to phase I ( 0 to 14 post-weaning). During the entire experimental period, pigs fed control and other experimental diets increased T cytotoxic and suppressor cells (CD8+), which contrasted with the decline in Thelper cells (CD4+) and granulocyte and monocyte proportions in week 3 after feeding (d 21 ) compared to week 1 after feeding (d 7). The decrease of T helper cells, granulocytes and monocytes between weeks 1 and 3 was higher in pigs fed diets supplemented with P-glycan, MOS, MG and NIS than in pigs fed the control diet. From d 15 to 28 post-weaning, the diarrhoea score was lower in pigs fed diets supplemented with any of the immunostimulators compared to phase I ( $\mathrm{d} 0$ to 14 after weaning), except for the NIS treatment. The diarrhoca symptom showed the largest improve-

\footnotetext{
* Partially supported by the KOSEF (Korea Science and Engineering Foundation) and $A$ gribrands Purina Korea, Inc.

Corresponding author
} 
ment in the MOS group, but there was no statistically significant difference among all of the treatments. In conclusion, these data suggest that the inclusion of immunostimulators (peptidoglycan, mannanoligosaccharides, $\beta$-glucan and NIS) has no beneficial effect on growth performance, except for mannanoligosaccharides. But the use of some immunostimulators showed a potential for weaned pigs to increase body growth (mannanoligosaccharides), return quickly to a low-key immune system (mannaolisosaccharides, $\beta$-glucan and NIS), reduce mortality ( $\beta$-glucan) and diarrhoea (mannanoligosaccharides).

KEW WORDS: peptidoglycan, mannanoligosaccharides, $\beta$-glucan, NIS, immune response, weaned pig

\section{INTRODUCTION}

A number of additives affect growth performance and immune response in weaned piglets. Peptidoglycan (mucopeptide, murein) is the basic component of the cell wall of Bifido-bacterium, a bacterium discovered in the intestine of healthy suckling babies in 1981. It has since been found to be an intestinal bacterium. The addition of 10 and $50 \mathrm{mg} / \mathrm{kg}$ of peptidoglycan decreased the incidence of diarrhoea and improved weight gain in piglets (Namioka et al., 1982).

Mannanoligosaccharides (MOS), carbohydrates derived from yeast cell wall, increase growth performance and immunity in domestic animals. D-mannose, the primary carbohydrate of MOS, presents on most cell surfaces and acts as a receptor for binding specific microbes, E. coli and Salmonella, to the cell surface (Ofek et al., 1977; Ofek and Sharon, 1990; Baba et al., 1993). Savage and Zakrzewska (1996) reported that yeast cell wall-derived mannanoligosaccharides stimulated immunity in turkeys. MacDornald (1996) also reported that mannanoligosaccharides reduced the mortality of broilers. Although the precise mechanism is not yet known, MOS enhances the protective immune response and has a beneficial effect on the growth of animals (Cotter, 1997). MOS also stimulates humoral and cellmediated immune responses. Spring and Privulescu (1998) reported that adding MOS led to an increase in both intestinal and serum IgG levels, intestinal lymphocytes and the phagocytic ability of white blood cells.

$\beta$-glucan is a structurally linear or branched polysaccharide present in the cell wall of yeast or fungi. The basic structure of the $\beta$-glucan from yeast is a $\beta$-D-(1-3) linked glucopyranosyl polymer with periodic $\beta-D-(1-6)$ linked side chains. Suzuki et al. (1990) reported that $\beta$-glucan derived from yeast cell wall stimulated nonspecific immune responses, and Schoenherr et al. (1994) reported that $\beta$-glucan increased growth performance in young pigs. Dritz ct al. (1995) also suggested that supplementing nursery pig diets with $\beta$-glucan reduces inflammatory immune responses, and increases growth performance. 
Nonspecific immunostimulating anionic alkali solution (NIS) has been recently developed for the purpose of enhancing growth rate and improving immunity in domestic animals. NIS is an anionic alkali solution ionized with inorganic compounds ( $\mathrm{Au}, \mathrm{Ag}, \mathrm{Si}, \mathrm{K}, \mathrm{Na}, \mathrm{S}, \mathrm{C}, \mathrm{H}_{2} \mathrm{O}$ ). It is known to improve growth performance, environmental conditions, meat quality and immunity. But the mode of action is not defined clearly.

Thus, this study was conducted to evaluate the effects of peptidoglycan, MOS, $\beta$-glucan and NIS on growth performance, nutrient and amino acid digestibilities, and immune response in pigs weaned at 21 days of age.

\section{MATERIAL AND METHODS}

One hundred and fifty, three-way crossbred [(Landrace $\mathrm{x}$ Large White) $\mathrm{x}$ Duroc] barrows and gilts weaned at 21 days of age were used as experimental subjects. Pigs averaging $6.6 \mathrm{~kg}$ body weight were chosen and allotted to treatments in a completely randomized block design.

The dosage of each feed additives (immunostimulators) was set according to the recommendations from supplier's research. Treatments included: 1. Control (basal diet), 2. P-glycan (basal diet +40 ppm peptidoglycan, PG-MIX $®$ Jeil Vet. Chem. Co., Korea), 3. MOS (basal diet $+0.1 \%$ mannanoligosaccharides, Bio-MOS $®$, Alltech Inc., USA), 4. MG (basal diet $+0.4 \% \beta$-glucan, MacroGard $®$, Jeil Vet. Chem. Co., Korea) and 5. NIS (basal diet $+300 \mathrm{ppm}$ Nonspecific Immunostimulating Anionic Alkali Solution, Baradon ${ }^{2}$, Angora Korea, Korea-rice bran used as a carrier). Each treatment had 6 replicates with 5 pigs per replicate.

The phase I ( $\mathrm{d} \mathrm{0-14)}$ diet was formulated to contain $3.43 \mathrm{Mcal} \mathrm{ME} / \mathrm{kg}, 1.69 \%$ lysine, the phase II (d 15-28) diet contained $3.43 \mathrm{Mcal} \mathrm{ME} / \mathrm{kg}$ and $1.39 \%$ lysine (Table 1). During the entire experimental period, feed and water were provided ad libitum. The temperature in the experimental boxes was maintained within a range of 26 to $30^{\circ} \mathrm{C}$ throughout the experimental period. Body weight and feed intake were recorded weckly and the diarrhoea score was recorded every day during the entire experimental period.

For determining the digestibility of experimental diets, pigs were fed diets containing $0.2 \% \mathrm{Cr}_{2} \mathrm{O}_{3}$ and faeces were collected three times a day for three days after a four-day adjustment period (before metabolic trial, all pigs were adjusted to experimental diets for one week to the diet of each phase). Faecal samples were dried in an air-forced drying oven at $60^{\circ} \mathrm{C}$ for $72 \mathrm{~h}$ and ground with $1 \mathrm{~mm}$ mesh Wiley mill.

Blood samples were collected for analysis of immune parameters at the end of each phase. After collection, blood samples were centrifuged and leukocytes were isolated using Hypaque-Ficoll (density 1.119, Sigma). Three monoclonal antibo- 
TABLE

Formula and chemical composition of the experimental diet

\begin{tabular}{|c|c|c|}
\hline & $\begin{array}{l}\text { Phase I } \\
\text { (d 0-14) }\end{array}$ & $\begin{array}{l}\text { Phase II } \\
\text { (d 15-28) }\end{array}$ \\
\hline \multicolumn{3}{|l|}{ Ingredients } \\
\hline maize & 22.67 & 33.00 \\
\hline whey, dried & 25.00 & 19.00 \\
\hline soyabean meal & 17.00 & 18.00 \\
\hline lactose & 10.00 & 10.00 \\
\hline soya oil & 4.50 & 4.50 \\
\hline fish meal (menhaden) & 10.00 & 7.00 \\
\hline rice bran polished & 3.00 & 3.00 \\
\hline spray dried blood meal & - & 2.00 \\
\hline spray dried plasma & 6.20 & 2.00 \\
\hline monocalcium phosphate & 0.30 & 0.27 \\
\hline limestone & 0.50 & 0.40 \\
\hline vitamin mixture' & 0.15 & 0.15 \\
\hline mineral mixture ${ }^{2}$ & 0.25 & 0.25 \\
\hline salt & 0.20 & 0.20 \\
\hline antibiotics & 0.03 & 0.03 \\
\hline \multicolumn{3}{|l|}{ Chemical composition ${ }^{3}$} \\
\hline $\mathrm{ME}, \mathrm{Mcal} / \mathrm{kg}$ & 3.43 & 3.43 \\
\hline crude protein. $\%$ & 23.84 & 21.01 \\
\hline Lys, $\%$ & 1.69 & 1.39 \\
\hline Met + Cys, \% & 0.42 & 0.32 \\
\hline Thr, $\%$ & 1.11 & 0.91 \\
\hline $\mathrm{Ca}, \%$ & 1.01 & 0.72 \\
\hline total P, \% & 0.86 & 0.66 \\
\hline available $\mathrm{P}, \%$ & 0.68 & 0.45 \\
\hline
\end{tabular}

${ }^{1}$ supplied per $\mathrm{kg}$ diet : 8,000 IU vitamin $\mathrm{A} ; 2,500 \mathrm{IU}$ vitamin $\mathrm{D}_{2} ; 30 \mathrm{IU}$ vitamin $\mathrm{E} ; 3$ mg vitamin $\mathrm{K}$ : $1.5 \mathrm{mg}$ thiamin; $10 \mathrm{mg}$ riboflavin: $2 \mathrm{mg}$ vitamin $\mathrm{B}_{5} ; 40 \mu \mathrm{g}$ vitamin $\mathrm{B}_{12}, 30 \mathrm{mg}$ pantothenic acid: $60 \mathrm{mg}$ niacin; $0.1 \mathrm{mg}$ biotin; $0.5 \mathrm{mg}$ folic acid

${ }^{2}$ supplied per kg diet: $200 \mathrm{mg} \mathrm{Cu}, 100 \mathrm{mg} \mathrm{Fe}, 150 \mathrm{mg} \mathrm{Zn,} 60 \mathrm{mg} \mathrm{Mn,} 1 \mathrm{mg} \mathrm{1,} 0.5 \mathrm{mg} \mathrm{Co}, 0.3 \mathrm{mg} \mathrm{Se}$

${ }^{3}$ calculate value

TABLE 2

A panel of monoclonal antibodies specifically reactive with swine leukocyte differentiation 3 antigens

\begin{tabular}{lccl}
\hline $\begin{array}{l}\text { Specificity } \\
\text { of MoAbs }\end{array}$ & $\begin{array}{c}\text { Monoclonal } \\
\text { antibodies }\end{array}$ & Cell cypes & \multicolumn{1}{c}{ References } \\
\hline PoCD4 & PT90A & T h/i cells & Hammerberg and Schuring, 1989 \\
PoCD8 & PT81B & T c/s cells & Hammerberg and Schuring, 1989 \\
G/M & DH59B & Granulocyte and monocyte & Davis et al., 1990 \\
\hline
\end{tabular}


dics specifically reactive with porcine leukocyte sub-populations were used to assay immune parameters (Table 2).

Analyses of nutrients of experimental diets and faecal samples followed the methods of AOAC (1990). Amino acid contents were determined, followed by acid hydrolysis with $6 \mathrm{~N} \mathrm{HCl}$ at 110 for $16 \mathrm{~h}$ (Mason, 1984), using an amino acid analyzer (Biochrom 20, Pharmacia Biotech, England). $\mathrm{Cr}_{2} \mathrm{O}_{3}$ was measured using an Atomic Absorption Spectrophotometer (Shimadzu, AA61 45F, Japan).

Statistical analysis was conducted using the GLM procedure of SAS (1990) and treatment means were compared using Duncan's multiple range test (Duncan, 1955).

\section{RESULTS}

The effects of peptidoglycan (P-glycan), mannanoligosaccharides (MOS), $\beta$-glucan (MG) and NIS on growth performance of weaned pigs are given in Table 3. Average daily gain (ADG) and feed conversion ratio (F/G) were similar in all groups from d 0 to 14 post-weaning. However, from d 15 to 28 post-weaning, $\mathrm{ADG}$ and $\mathrm{F} / \mathrm{G}$ were better in the MOS group than in the MG and NIS groups

TABLE 3

Effects of P-glycan, MOS, MG and MS on growing performance in weaned pigs*

\begin{tabular}{lcccccr}
\hline Item & Control & P-glycan & MOS & MG & NIS & SE $^{\prime}$ \\
\hline Phase I, d 0-14 & & & & & & \\
ADG, g & 352 & 326 & 349 & 349 & 317 & 8.16 \\
ADFI, g & 399 & 387 & 414 & 430 & 378 & 11.68 \\
F/G & 1.14 & 1.19 & 1.19 & 1.22 & 1.19 & 0.01 \\
& & & & & & \\
Phase II, d 15-28 & & & & & & \\
ADG, g & $514^{\text {ah }}$ & $521^{\text {th }}$ & $532^{\mathrm{a}}$ & $477^{\mathrm{c}}$ & $497^{\mathrm{h}}$ & 9.12 \\
ADFI, g & 652 & 655 & 636 & 581 & 606 & 15.36 \\
F/G & 1.27 & 1.26 & 1.20 & 1.21 & 1.22 & 0.02 \\
& & & & & & \\
Overall, d 0-28 & & & & & & \\
ADG, g & 433 & 423 & 441 & 413 & 407 & 7.16 \\
ADFl, g & 525 & 521 & 525 & 506 & 492 & 11.28 \\
F/G & 1.22 & 1.23 & 1.19 & 1.21 & 1.21 & 0.01 \\
\hline
\end{tabular}

* abbreviation: $\mathrm{P}$ - glycan; petidoglycan. MOS; mannanoligosaccharide, MG; $\beta$-glucan. NIS: non-specific anionic alkali solution, ADG; average daily gain, 6 ADFI; average daily feed intake, F/G: feed/gain ratio

1 pooled standard error

wh. $\mathrm{P}<0.05$ 
$(\mathrm{P}<0.05)$. Pigs fed diets with MOS or $\mathrm{P}$-glycan showed similar growth performance as those fed the control diet. MG and NIS treatments did not support pig growth at a similar rate as pigs in the control, MOS and P-glycan groups.

The digestibility of diets supplemented with P-glycan, MOS, MG and NIS is shown in Table 4. During phase I ( $\mathrm{d} 0$ to 14 after weaning), the digestibility of dry matter (DM) was similar in all groups. Crude protein (CP) digestibility of the control diet was significantly higher than of diets supplemented with P-glycan, MOS, MG or NIS $(\mathrm{P}<0.05)$. However, crude ash $(\mathrm{CA})$, calcium $(\mathrm{Ca})$ and phosphorus $(\mathrm{P})$ digestibilities were not significantly different among treatments. During phase II (d 15 to 28 post-weaning), digestibilities of $\mathrm{DM}, \mathrm{CP}$ and ether extract (EE) were significantly higher in pigs fed the diet supplemented with MOS than other treatments $(\mathrm{P}<0.05)$. Crude ash, $\mathrm{Ca}$ and $\mathrm{P}$ digestibilities were highest in the NIS group.

TABLE 4

Effects of P-glycan, MOS, MG and NIS on nutrients digestibilities in weaned pigs

\begin{tabular}{|c|c|c|c|c|c|c|}
\hline ltem & Control & P-glycan & MOS & MG & NIS & $\mathrm{SE}^{\prime}$ \\
\hline \multicolumn{7}{|c|}{ Phase I. d 0-14, \% } \\
\hline crude protein & $77.40^{a}$ & $75.83^{\text {ub }}$ & $76.45^{\text {ab }}$ & $75.18^{\mathrm{ah}}$ & $73.39^{\mathrm{b}}$ & 0.56 \\
\hline ether extract & 67.86 & 67.77 & 67.33 & 65.96 & 69.58 & 1.19 \\
\hline crude ash & 50.36 & 55.86 & 53.21 & 48.10 & 51.74 & 1.70 \\
\hline $\mathrm{Ca}$ & 90.87 & 92.04 & 90.80 & 89.11 & 91.08 & 0.47 \\
\hline $\mathrm{P}$ & 52.73 & 61.10 & 57.32 & 46.76 & 57.84 & 2.33 \\
\hline \multicolumn{7}{|c|}{ Phase II, d 0-28, \% } \\
\hline dry matter & $79.69^{\mathrm{h}}$ & $81.66^{\mathrm{Ath}}$ & $83.01^{*}$ & $80.88^{\text {ab }}$ & $80.20^{\mathrm{h}}$ & 0.39 \\
\hline crude protein & $74.55^{\mathrm{h}}$ & $77.50^{\text {ath }}$ & $78.45^{a}$ & $75.35^{\text {bh }}$ & $76.59^{\text {ah }}$ & 0.50 \\
\hline ether extract & $49.86^{\mathrm{hc}}$ & $51.81^{\mathrm{ah}}$ & $60.14^{a}$ & $46.23^{i}$ & $55.98^{\mathrm{ah}}$ & 1.58 \\
\hline crude ash & 45.31 & 46.43 & 50.79 & 44.13 & 51.67 & 1.46 \\
\hline $\mathrm{Ca}$ & 89.67 & 88.50 & 89.50 & 88.21 & 89.70 & 0.40 \\
\hline $\mathrm{P}$ & 48.71 & 41.64 & 44.99 & 47.64 & 48.81 & 1.71 \\
\hline
\end{tabular}

Amino acid digestibilities of diets supplemented with different immunostimulators are given in Tables 5 and 6. During d 0 to 14 post-weaning, essential (EAA) and non-essential amino acid (NEAA) digestibilities were similar except NIS and which was higher $(\mathrm{P} \leq 0.05)$ in pigs fed the control and $\mathrm{MG}$ diets. Total amino acid digestibilities were slightly higher in pigs fed the control diet than in other groups, however, the differences were not significant. In phase II (d 15 to 28 post-weaning), EAA digestibility was improved in pigs fed P-glycan, MOS and NIS 
TABLE 5

Effects of P-glycan, MOS, MG and NIS on amino acids digestibilitics in wcaned pigs during phase I, d. $0-14$

\begin{tabular}{lccllll}
\hline Item & Contro! & P-glycan & MOS & MG & NIS & SE \\
\hline Essential amino acids, \% & & & & & \\
Thr & 75.35 & 72.15 & 76.18 & 77.71 & 75.59 & 1.19 \\
Val & 75.26 & 68.80 & 73.07 & 76.65 & 69.96 & 1.35 \\
Met & 74.05 & 71.18 & 74.92 & 72.99 & 75.95 & 1.04 \\
Ilc & 75.01 & 70.62 & 73.69 & 75.64 & 71.82 & 1.12 \\
Leu & 78.65 & 70.87 & 74.29 & 77.42 & 72.69 & 1.23 \\
Phe & 73.60 & 63.95 & 67.62 & 71.05 & 70.07 & 1.38 \\
His & $77.45^{\text {a }}$ & $68.94^{\text {ah }}$ & 69.31 ah & $74.46^{\text {a }}$ & $63.65^{\text {h }}$ & 1.65 \\
Lys & 83.62 & 76.03 & 79.07 & 82.40 & 76.46 & 1.19 \\
Arg & 87.55 & 81.11 & 85.70 & 87.17 & 84.87 & 1.00 \\
Submean & 77.84 & 71.52 & 74.87 & 77.28 & 73.45 & 1.10 \\
& & & & & & \\
Non-essential amino acids, \% & & & & & \\
Asp & 77.23 & 71.95 & 70.95 & 80.73 & 73.93 & 2.13 \\
Ser & 79.24 & 77.28 & 79.89 & 81.30 & 78.92 & 1.00 \\
Glu & 84.50 & 80.99 & 82.49 & 84.79 & 82.68 & 0.81 \\
Pro & 77.80 & 77.81 & 68.99 & 65.65 & 74.04 & 2.27 \\
Ala & 74.38 & 70.00 & 73.50 & 75.43 & 71.85 & 1.18 \\
Tyr & 71.04 & 65.34 & 69.55 & 71.68 & 67.58 & 1.37 \\
Submean & 74.92 & 71.43 & 72.72 & 78.81 & 72.53 & 1.10 \\
Total & 77.01 & 73.54 & 74.01 & 96.92 & 74.51 & 0.99 \\
\hline
\end{tabular}

${ }^{1}$ pooled standard error

a.b $\mathrm{P}<0.05$

compared to the control group. Total amino acid digestibility was significantly higher in pigs fed MOS than in control $(\mathrm{P}<0.05)$.

Table 7 shows the effects of P-glycan, MOS, MG and NIS on leukocyte subpopulations in weaned pigs. During the entire experimental period, pigs fed control and other experimental diets increased $T$ cytotoxic and suppressor cells (CD8+), in contrast with $\mathrm{T}$ helper cells (CD4t), and the proportion of granulocytes and monocytes was decreased on day 21 (week 3 after weaning) compared with day 7 (week 1 after weaning). The decreases of T helper cells (CD4+), granulocytes and monocytes between weeks 1 and 3 after weaning were higher in pigs fed diets supplemented with immunostimulators (P-glycan, MOS, MG and MS) than in those fed the control diet. But there was no significant difference among treatments in all immunc parameters.

Mortality and diarrhoea score in weaned pigs fed experimental diets are presented in Table 8 . Mortality of pigs fed P-glycan and MG was lower than in other 
TABLE 6

Effects of P-glycan, MOS, MG and NIS on amino acids digestibilities in weaned pigs during phase II. d $15-28$

\begin{tabular}{|c|c|c|c|c|c|c|}
\hline Item & Control & P-glycan & MOS & MG & NIS & SE \\
\hline \multicolumn{7}{|c|}{ Essential amino acids, \% } \\
\hline Thr & 77.50 & 81.36 & 82.15 & 75.30 & 77.30 & 1.10 \\
\hline Val & $73.80^{\mathrm{bc}}$ & $79.77^{\text {ab }}$ & $78.39^{\text {ah }}$ & $71.50^{\circ}$ & $80.82^{:}$ & 1.14 \\
\hline Met & 71.65 & 72.98 & 73.25 & 68.03 & 74.71 & 0.98 \\
\hline Ile & $71.13^{b}$ & $78.44^{4}$ & $76.96^{\mathrm{ah}}$ & $71.09^{\mathrm{h}}$ & $78.01^{:}$ & 1.14 \\
\hline Leu & $65.53^{\text {ah }}$ & $71.65^{a}$ & $70.99^{\mathrm{ah}}$ & $61.51^{\mathrm{b}}$ & $72.32^{i}$ & 1.56 \\
\hline Phe & 78.24 & 78.96 & 79.88 & 78.53 & 80.64 & 0.69 \\
\hline His & 77.44 & 78.45 & 81.51 & 74.77 & 80.18 & 0.99 \\
\hline Lys & $77.75^{\mathrm{h}}$ & $84.60^{\prime \prime}$ & $83.80^{\mathrm{ah}}$ & $77.86^{b}$ & $82.28^{\text {th }}$ & 1.06 \\
\hline Arg & $84.50^{\mathrm{ab}}$ & $88.31^{\prime \prime}$ & $87.82^{\text {ah }}$ & $85.32^{\text {ah }}$ & $82.36^{\mathrm{h}}$ & 0.86 \\
\hline Submean & 75.28 & 79.39 & 79.41 & 73.76 & 78.74 & 0.89 \\
\hline \multicolumn{7}{|c|}{ Non-essential amino acids, $\%$} \\
\hline Asp & $78.22^{\mathrm{h}}$ & $84.14^{\text {ath }}$ & $83.08^{\text {:lb }}$ & $87.23^{i}$ & $80.30^{\mathrm{iht}}$ & 1.16 \\
\hline Ser & 81.31 & 84.55 & 85.36 & 79.24 & 81.09 & 0.98 \\
\hline Glu & 81.35 & 84.13 & 84.55 & 85.52 & 79.04 & 1.17 \\
\hline Pro & $80.65^{h}$ & $81.80^{\mathrm{aht}}$ & $86.55^{\lrcorner}$ & $83.11^{\text {ith }}$ & $79.00^{\mathrm{r}}$ & 0.89 \\
\hline $\mathrm{Ala}$ & $75.70^{2}$ & $72.14^{\mathrm{ah}}$ & $79.35^{\circ}$ & $71.20^{\mathrm{ath}}$ & $64.80^{\mathrm{b}}$ & 1.56 \\
\hline Tyr & $70.08^{\circ}$ & $80.19^{\mathrm{ab}}$ & $75.87^{\mathrm{hi}}$ & $68.51^{c}$ & 86.54 & 1.81 \\
\hline Submean & 72.68 & 76.84 & 78.37 & 74.80 & 76.05 & 1.18 \\
\hline Total & $77.20^{\mathrm{h}}$ & $80.54^{\mathrm{ah}}$ & $81.87^{a}$ & $78.52^{\text {ih }}$ & $78.1 !^{\mathrm{ith}}$ & 0.68 \\
\hline
\end{tabular}

${ }^{1}$ pooled standard error

w.h $\mathrm{P}<0.05$

TABLE 7

Effects of P-glycan, MOS, MG and MS on proportion of leukocyte sub-populations in weaned pigs

\begin{tabular}{lcccccc}
\hline \multirow{2}{*}{ Item, \% } & \multicolumn{5}{c}{ Treatment } & \multirow{2}{*}{ SE $^{\prime}$} \\
\cline { 2 - 5 } & Control & P-glycan & MOS & MG & NIS & \\
\hline Day 7 & & & & & & \\
CD4 & 36.55 & 38.64 & 41.46 & 40.33 & 41.73 & 1.99 \\
CD8 & 17.04 & 17.89 & 14.51 & 16.98 & 16.89 & 1.56 \\
G and M & 40.98 & 42.01 & 47.99 & 44.19 & 44.46 & 3.68 \\
& & & & & & \\
Day 21 & & & & & & \\
CD4 & 23.40 & 17.95 & 17.36 & 17.31 & 19.17 & 1.35 \\
CD8 & 20.59 & 23.91 & 23.91 & 26.00 & 28.45 & 1.45 \\
G and M & 30.32 & 30.03 & 32.04 & 25.18 & 32.00 & 1.68 \\
\hline
\end{tabular}

* blood samples were collected from four pigs per treatment to investigate leukocyle sub- population

' pooled standard error

2 granulocyte and monocyte 
TABLE 8

Effects of P-glycan, MOS. MG and NIS on mortality and diarrhoea score in weaned pigs

\begin{tabular}{lcccccc}
\hline \multirow{2}{*}{ ltem. \% } & \multicolumn{5}{c}{ Treatment } & SE' \\
\cline { 2 - 5 } & Control & P-glycan & MOS & MG & NIS & \\
\hline $\begin{array}{l}\text { No. of pigs } \\
\text { phase I, d 0-14 }\end{array}$ & 30 & 30 & 30 & 30 & 30 \\
phase II. d 15-28 & 27 & 28 & 27 & 30 & 26 \\
Mortality, \% & 10.00 & 6.67 & 10.00 & 0.00 & 13.33 \\
Diarrhoea score? & & & & & & \\
phase I, d 0-14 & 3.9 & 4.0 & 3.9 & 4.0 & 4.4 & 0.2 \\
phase II. d 15-28 & 2.5 & 2.3 & 2.1 & 2.3 & 2.5 & 0.2 \\
\hline
\end{tabular}

pooled standard error

2 1. hard; 2 . normal; 3 . soft; 4. more soft; 5 . watery

groups, while mortality in pigs fed MOS was equal to pigs fed the control diet. The diarrhoca score was lowest in pigs fed the control diet during phase I, however, during phase II, the diarrhoea score was lower in pigs fed diets supplemented by any of immunostimulators compared to phase I, except in the MS treatment; the diarrhoea score was most improved in the MOS group. However, there were no significant differences among the treatments.

\section{DISCUSSION}

Pigs fed MOS for both periods showed better growth performance and grew more efficiently than other groups, although the difference was not significant. This result corresponds with that of a study by Vander Beke (1997) that the supplementation of mannanoligosaccharides and the combination of mannanoligosaccharides plus Lacto-Sacc improved piglet performance. However, other immunostimulators, especially $\beta$-glucan (MG), did not show improvement in growth rate and feed efficiency in the present study. A number of rescarchers have investigated the effect of $\beta$-glucan in pigs and reported positive results. According to Dritz et al. (1995), the inclusion of $\beta$-glucan decreased inflammatory cytokine production and increased ADFI and ADG. Schoenherr ct al. (1994) evaluated growth performance of weanling pigs ( $19 \mathrm{~d}$ old) fed diets containing $0,0.025,0.05,0.075$, 0.1 and $0.125 \% \beta$-glucan. Although no improvement in growth was observed during the first 2 weeks, $\beta$-glucan improved overall ADG. This result is more or less in line with the results of the current study. Schoenherr et al. (1994) concluded that the optimal inclusion level of $\beta$-glucan is between 0.025 and $0.05 \%$ when fed throughout the nursery period. The inclusion level of $\beta$-glucan in the present study 
was higher than in the previous study, but differences may arise among preparations due to their origin and processing method.

Although ADG and ADFI were lower in all groups supplemented with immunostimulators compared to the control group during phase I ( $\mathrm{d} 0$ to 14 post-weaning), all treated groups showed better growth performance, especially in the P-glycan and MOS groups during phase Il. Given this result, one can speculate that the pigs may have been challenged by some viruses or pathogens, which are common under commercial conditions, so they use more energy and nutrients in establishing the immune system in the early stage of experiment. But, in the late stage of experiment, pigs fed diets supplemented with immunostimulators showed faster recovery and better growth than the control group. According to Williams et al. (1993a,b), pigs with low-key immune systems consumed more feed, grew faster and required less feed per unit of gain than those in the high immune status (IS) group. The general response of the immune system to an antigen is initiated by a release of a series of compounds called cytokines. Cytokine release also alters various endocrine pathways and metabolic processes (Stahly, 1996). ACTH and thyroxine, which are catabolic hormones, are elevated (Navarra et al., 1991; Hashimoto, 1994), in contrast, thymic and somatotropic peptides, which are potential anabolic hormones, are inhibited (Hannager et al., 1991; Fan et al., 1994). In metabolic processes, voluntary feed intake is lowered (Mrosovsky et al., 1989; Johnson and von Borell, 1994). Body protein synthesis is reduced, and more body proteins are degraded (Klasing et al., 1987; Ballmer et al., 1994). These metabolic changes result in a reduced growth rate, less efficient utilisation of feed for growth and potentially fatter carcasses (Stahly, 1996).

The pigs with low-key immune systems possessed fewer CD4 positive T-lymphocytes, more CD8 positive T-lymphocytes, and lower CD4:CD8 ratios than pigs with highly stimulated immune systems (William et al., 1993a,b; Stahly, 1996). From the present study, the CD4-positive T-lymphocyte population was higher in all treated groups during week 1 after feeding (d 7) than in the control group, but that was lowered at $\mathrm{d} 21$ (week 3 after weaning) in all treatments compared with the control. And, the CD8-positive T-lymphocyte population was also higher in pigs fed diets supplemented with immunostimulators than pigs fed the control diet during the late experimental period, which means that the pigs fed diets containing immunostimulators showed a lower-key immune system than pigs fed the control diet during the late experimental period. Therefore, it might said that all immunostimulators used in this study showed a non-specific immunostimulating effect, although their effect on growth seems to be very slight.

In general, when immune responses occur, amino acids are lost from skeletal muscle due to enhanced proteolysis and decreased protein synthesis. Thus, the amino acids are used for synthesis of acute-phase proteins in the liver, oxidized for producing energy, used as glyconeogenic substrates and used for protein synthesis 
in leukocytes to support clonal expansion and secretion of immunoglobulin and regulatory proteins (Klasing et al., 1987). The use of immunostimulators therefore decreases the loss of amino acids by protecting from invasion of harmful pathogens and diseases, and consequently improves the growth rate in domestic animals. In the current study, some amino acids (lysine, leucine and isoleucine, etc.), which are generally known to be related to immunocompetence, showed improved digestibility (except threonine) during phase II (d 15 to 28 post-weaning) compared to phase I ( $\mathrm{d} 0$ to 14 post-weaning). But, these digestibilities could not exactly explain the metabolism or repartitioning of amino acids in the animal body, whether they are used in muscle deposition or immune protein synthesis. Therefore, further research is required to elucidate the metabolism of amino acids during immune challenge.

As shown in Table 8, the diarrhoea score was lowest in the MOS group during the entire experimental period, although there was no significant difference among treatments. Originally, the main role of MOS is the inhibition of microbial adherence to cell surface, that is to say, it acts as a receptor for binding specific microbes, E. coli and Salmonella, to the host cell surface (Ofek et al., 1977; Ofek and Sharon, 1990; Baba et al., 1993). It is known that E. coli and Salmonella are harmful organisms causing diarrhoea in young pigs, therefore it may be said that the reduction of diarrhoea explains the role of MOS in the intestinal cells of piglets. These previous studics and results illustrate the purpose of using MOS in animal feed, and the present study also shows corroborating results. According to MacDonald (1996), supplementation of mannanoligosaccharides reduced the mortality of broilers. The present study, however, does not elucidate the effect of MOS on reduction of mortality in weaned pigs. P-glycan treatment led to a lower mortality than the other treatments in the present study.

\section{CONCLUSIONS}

The present study suggests that the inclusion of immunostimulators (pcptidoglycan, mannanoligosaccharides, $\beta$-glucan and NIS) has no beneficial effect on growth performance, except for mannanoligosaccharides. But the use of some immunostimulators showed potential for weaned pigs, increased rate of body growth (mannanoligosaccharides), fast return to low-key immune system (mannaolisosaccharides, $\beta$-glucan and NIS), reduced mortality ( $\beta$-glucan) and decreased diarrhoea (mannanoligosaccharides). However, the present data is insufficient for drawing final conclusions and is a preliminary step showing the possibilities open to using immunostimulators and in evaluating the mechanism of their action. Thereforc, further research should be done to identify the physiological and metabolic changes caused by adding immunostimulators to dicts for weaned pigs. 


\section{REFERENCES}

AOAC, 1990. Official Methods of Analysis. 15th Edition. Association of Official Analytical Chemist. Washington, DC

Baba E.. Tsukamoto Y., Fukata T., Sasai K., Arakawa A., 1993. Increase of mannose residues, as Salmonella typhimurium-adhering factor, on the cecal mucosa of germ-free chickens infected with Eimeria tenella. Amer. J. Vet. Res. 54. 1471-1477

Ballmer P.E., McNurlan M.A.. Southorn B.G., Grant L. Garlic P.T., 1991. Effects of human recombinant interleukin- 1 beta on protein synthesis in rat tissues compared with classic acute phase reaction induced by turpentine. Biochem. J. 279, 683-692

Cotter P.F., 1997. Modulation of the immune response: current perceptions and future prospects with an example from poultry. Biotechnology in the Feed Industry. Proceedings of Alltech's Thirteenth Annual Symposium. pp. 195-203

Davis W.C., Hamilton M.J., Park Y.H., 1990. Ruminant leukocyte differentiation molecules. In: Barta. MHC, Differentiation Antigen and Cytokines in Animal and Birds. Monographs in Animal Immuno. Blacksburg. VA:BAR-1, AB. Inc., pp. 47-70

Dritz S.S., Shi J., Kielian T.L., Goodband R.D., Nelssen J.L., Tokach M.D., Chengappa M. M., Smith J.E., Blecha F. 1995. Influence of dietary $\beta$-glucan of growth performance, nonspecific immunity, and resistance to Streptococcus suis infection in weanling pigs. J. Anim. Sci. 73. $3341-3350$

Duncan D.B., 1955. Multiple range and multiple F tests. Biometrics 11.1

Fan J., Molina P.E., Gelato M.C., Lang C.H., 1994. Differential tissue regulation of insulinlike growth factor-I content and binding proteins after endotoxin administration. Endocrinology $34,1685-1696$

Hammerberg C.. Schurig G.G., Ochs D.L., 1989. Immunodeficiency in young pigs. Amer. J. Vet. Res. 50, $868-874$

Hannager S., Spagnoli A., D'Urso R., Navarra P., Tsagarkis S., Besser M., Grossman A.B., 1991. Interleukin-l modulates the acute release of growth hormonc-releasing hormone and somatostatin from rat hypothalmus in vitro, whereas tumor necrosis factor and interleukin 6 have no effect. Endocrinology 129, 1275-1288

Hashimoto H., Igarashi N., Yachie A., Migawaki T., Sato T., 1994. Relationship between serum levels of interleukin- 6 and thyroid hormone in children with acute respiratory infection. J. Clin. Endocrinol, Mctab. 78, 288-297

Johnson R.W., von Borell E., 1994. Lipopolysaccharide-induced sickness behavior in pigs is inhibited by pretreatment with indomethacin. J. Anim. Sci. 72, 309-314

Klasing K.C., Laurin D.E., Peng R.K., Fry D.M., 1987. Immunologically mediated growth depression in chicks: influence of feed intake, corticosterone and interleukin- J. J. Nutr. 117, 16291637

MacDonald F., 1996. Use of immunostimulants in agricultural applications. In: T.P. Lyons, K.A. Jacques (Editors). Biotechnology in the Feed Industry. Nottinghanm University Press, Nottingham (UK), pp. 97-103

Mason V.C., 1984. Metabolism of nitrogenous compound in the large gut (Emphasis on recent lindings in the sheep and pig). Proc. Nutr. Soc. 43, 45-52

Mrosovsky N., Molony L.A., Conn C.A., Kluger M. J., 1989. Anorexic effects of interleukin 1 in the rat. Amer. J. Physiol. 257, 135-146

Namioka T., Sasaki T., Inabe N., 1982. Immunopetentiation of the mucosa of the small intestine of weaning piglets by PG. Jpn. J. Ve1. Sci. 49, 235-242 
Navarra P., Tsagarakis S.. Fairia M., Rees L.H., Besser G.M.. Grossman A.B.. 1991. Interleukin-1 and -6 stimulate the release of corticolropin releasing hormone-41 from rat hypothalmus in vitro via the eicosanoid cyclooxygenase pathway. Endocrinology $128,32-42$

NRC, 1998. Nutrient Requirements of Swine. 10th Edtion. National Academy Press, Washington, DC

Ofek L., Mirelman D., Sharon N., 1977. Adherence of Escherichia coli to human mucosal cells mediated by mannose receptors. Nature 265, 623-641

Ofek L.. Sharon N., 1990. Adhesions as lectins: Specificity and role in infection. Curr. Top. Microbiol. Immunol. 151, 92-101

SAS, 1990. SAS User's Guide : Statistics, SAS Inst. Inc. Cary, NC

Savage T.F., Zakrzcwska E.L, 1996. The performance of male turkeys fed a starter diet containing a mannanoligosaccharide (Bio-Mos) from day old to eight weeks of age. In: T.P. Lyons, K.A. Jacques (Editors). Biotechnology in the Feed Industry. Nottingham University Press, Nottingham (UK), pp. 47-54

Schoenherr W.D., Pollmann D.S., Coalson J.A., 1994. Titration of MacroGard ${ }^{\mathrm{TM}}-\mathrm{S}$ on growth performance of nursery pigs. J. Anim. Sci. 72, Suppl. 2, 57 (Abstr.)

Spring P., Privulescu M., 1998. Mannanoligosaccharide: Its logical rolc as a natural feed additive for piglets. Proceedings of 8th WCAP, Pre-Conference Symposia. Seoul (Korea). pp. 21-27

Suzuki L. Tanaka H., Kimoshita A., Oikawa S., Osawa M., Yadomae T.. 1990. Effect of orally administered $\beta$-glucan on macrophage function in mice. Int. J. Immunopharmacol. 12, 675-683

Stahly T., 1996. Impact of immune system activation on growth and optimal dietary regimens of pigs. In: J. Garnsworthy, J. Wiscman. W. Haresign (Editors). Recent Advances in Animal Nutrition. Nollingham University Press, Nottingham (UK), pp. 197-206

Vander Beke N., 1997. Het gebruik van mannanoligosaccharide en lactobacillen in bggenvoeders. Thesis. Highschool Gent, Department of Biotechnological Sciences, Landscape Management and Agriculiure, Gent (Belgium)

Wiliams N.H, Sthaly T.S., Zimmerman D.R., 1993a. Impact of immune system activation and dielary amino acid regimen on nitrogen retention in pigs. J. Anim. Sci. 71, Suppl. 1, 171 (Abstr.)

Williams N.H. Sthaty T.S., Zimmerman D.R., Wannemuehler M., 1993b. Impact of immune system activation on the amino acid needs of pigs. J. Anim. Sci. 7l, Suppl. 1,61 (Abstr.) 


\section{STRESZCZENIE}

\section{Wplyw immunostymulatorów na rozwój i reakcję odpornościową prosiąt odsadzonych w 21 dniu życia}

Sto pięćdziesiąt prosiąt o średniej m.c. $6,6 \mathrm{~kg}$ podziclono do grup doświadczainych na zasadzie bloków kompletnic zrandomizowanych: 1. kontrolna (dawka podstawowa), 2. P-glikan (dawka podstawowa +40 ppm peptydoglikanu), 3. MOS (dawka podstawowa $+0,1 \%$ mannanoligosacharydów), 4. MG (dawka podstawowa $+0,4 \% \beta$-glukanu) i 5 . NIS (dawka podstawowa $+300 \mathrm{ppm}$ Niespecyficznego Zasadowego Roztwora Immustymulującego), z otrębami ryżowymi jako nośnik. Każda grupa miała 5 powtórzeń, po 5 prosiąt w każdym. Chociaż nie stwierdzono istotnych różnic w rozwoju prosiąt, to zwierzęta otrzymujące dawkę MOS lepiej przyrastały i lepiej wykorzystywały paszę niż pozostałe. W drugim okresie doświadczenia (15-28 dni po odsadzeniu) prosięta lepiej trawiły składniki pokarmowe i aminokwasy dawek niż w okresie pierwszym (0-14 dni po odsadzeniu). W ciagu całego doświadczenia u prosiąt wszystkich grup zwiększyła się liczba komórek T cytotoksycznych i hamujących (CD8+), a obniżyła konłórek T wspomagających (CD4+) oraz zawartość granulocytów i monocytów w 21 dniu życia w porównaniu z 7 dniem życia. Obniżenie komórek T wspomagających, glukocytów i monocytów między l a 3 tygodniem było większe u prosiąt otrzymujących diety z dodatkiem P-glikanu, MOS, MG i NIS niż u kontrolnych. Od 15 do 28 dnia po odsadzeniu, wskaźnik biegunek był niższy u prosiąt otrzymujących diety z każdym z dodatków immunostymulujących w porównaniu z okresem pierwszym (0-14 dni po odsadzeniu), z wyjątkiem grupy NIS. Największą poprawę wskaźnika bicgunek stwierdzono w grupic MOS: różnice jednak nie były starystycznie istorne.

W podsumowaniu stwierdzono, że otrzymane wyniki wskazuja, że dodatek immunostymulatorów (peptydoglikan, mannoligosacharydy, $\beta$-glukan i NIS) nic wpływa dodatnio na rozwój prosiąt, $z$ wyjątkicm mannoglikosacharydów. Dodatek niektórych immunostymulatorów dla odsadzonych prosiąt może być skuteczny dla zwiçkszenia przyrostów (mannoglikosacharydy, $\beta$-glukan i NIS), obniżenia śmiertelności ( $\beta$-glukan) i występowania biegunek (mannoglikosacharydy). 